\title{
MICRO INSURANCE: A TOOL FOR DEVELOPMENT OF RURAL INDIA AND THE CHALLENGES FOR ITS IMPLEMENTATION
}

KEY WORDS: IRDA, Micro insurance, Challenges, NGO

\section{Dr Seena P. C}

Assistant Professor, Department of Commerce Government College Mananthavady,Wayanad Kerala, India.

Micro-insurance is originated for the protection of poor and low income people, with feasible insurance schemes to help them to survive and recover from common risks. The main aim of micro insurance is not only to promote business perspective but also to the rural development of our country and the protection of poor people. India is developing country hence $70 \%$ of the population is still rural, very poor, poor health and low literacy rate. Micro insurance is an essential part of the financial sector and it assists the people to diversify their risks. It is essential to develop insurance awareness among the people in the each and every corner of our country particularly remote area. The present study focussed the importance of micro insurance for the development of rural people. This paper also discuss about the micro insurance products and the role of various public and private micro insurance agents for the upliftment of rural and poor people.

\section{INTRODUCTION}

Micro insurance is to protect the group of low income people against specific perils. It is a new concept introduced in 2005 by IRDA (Insurance Regulatory and Development authority) to facilitate insurance coverage to poor. Micro insurance is really originated from the concept micro finance. Micro insurance aims to protect lives of poor people in developing country from the shocks that affect their livelihoods such as illness, accidents, death, and loss of assets like animals, crops and machinery. It provides economic security to poor and low income people and act as risk mitigation strategy. It can be noted that the postal life insurance is very effective and worthwhile form of micro insurance. Micro insurance schemes include life, health, property, disability and other scheme related to crop.

\section{Literature Review}

Rajeev Ahuja, Basudeb Guha-Khasnobis (2005) ${ }^{8}$ : A study titled "Micro-Insurance in India Tends and Strategies for further extension" analysis the link between micro credit and micro insurance. At present micro insurance business in the country is unregulated. Regulation of MFIs is needed not only to promote micro finance activity in the country but also to promote the linking of micro insurance with micro-finance.

Basanta K.Sahu(2010) ${ }^{12}$ : In his study titled "Micro insurance: outreach and efficacy" explains in many contexts the existing micro insurance products are not demand driven in both high and low outreach areas. There is lack of understanding, awareness, extension services and development of insurance market that grossly affect wider use of insurance products and its uptake, particularly, among low income groups.

Bhatt Shilpa R,(2012)": A study titled "A study of financial performance Appraisal of Life Insurance Corporation of India", attempts to find out people are aware about life insurance and therefore the quantum of coverage for life insurance has increased by more than ten times in span of 20 years.

Farah Farooque $\left(2013^{13}\right.$ :A study on the topic "Role of micro finance institutions in Micro insurance" explains the role of MFIs in creating insurance awareness and distributing micro insurance products. The analysis witness that their role is ineffective in creating awareness and distributing products. MFIs faces problem in creating awareness and distributing products ie lack of staffing, illiteracy, lack of resources, negative approach towards micro insurance.

Sanjeev Kumar Srivastawa(2013) ${ }^{16}$ : Topic "Micro insurance: a Spectacular View on Rural Development in India" explains micro insurance protects rural as well as urban people by offering low cost insurance. Study mainly focus on the present position of micro insurance in India and its role in respect of risk mitigation and economic upliftment.

Erika Binnendijk(2014) ${ }^{14}$ : A study titled "Designing Community-Based health insurance among rural poor in India: A novel time and cost-effective method for data sourcing" examines health related hardship financing in order to get better insights on how poor households finance their out of pocket health care costs. It was found that $25 \%$ of the households reported hardship financing.

\section{Objectives of the study}

The present study has been carried out to achieve the following specific objectives:

- To study the role of micro insurance for upliftment of rural India

- To know the micro insurance players and its products.

- To understand the different types of micro insurance.

- To examine the problems, issues, and key challenges in micro insurance.

\section{Methodology of the study}

The study has been conducted mainly on the basis of literature survey and secondary information.Various journals, research papers, annual reports, and newspaper articles have been surveyed in making this study.

\section{Role of micro insurance in rural areas}

Micro insurance is a potential new risk management tool for low income people. It can be noted that about $70 \%$ of Indian population resides in rural area and they have limited access to insurance coverage. Rural area of our country is dominated by poor and engaging in agricultural activity. Majority depend on agriculture for their livelihood. They are less educated and not aware of various mechanisms for reducing risk. Rural people have to face various risks that is mainly household related risk, risk due to disaster, health, unemployment, old aged problems illness, accidents and sudden death. Natural disasters, it is unpredictable that affects the poor people to a great extent specifically lives, health, housing and income generating activities. Natural calamities adversely affect the agriculture sector and it will create hindrance in the sustainable growth of the country. Poverty reduction mainly depends on agricultural development in rural area. Production risk, market risk, pest risk investment and credit risk are the various risks associated with the agriculture. Production risk mainly the risk associated with rainfall, variation in temperature, solar radiation and pest risk related soil, its fertility, $\mathrm{PH}$ texture, pest management and irrigation. Micro insurance, as a tool for mitigation of risk helps the people who are economically weak to cope with such problems. 
Micro insurance facilitates the financial services package to people belongs to the group of low income levels. It offers mechanism to manage risk and to contribute to programme of government for poverty alleviation. In 2003, a consultive group formed by Government of India to study the present status of existing schemes of micro insurance, particularly in rural India. The group opined that, the micro insurance expansion in rural India was not noticeable. Micro insurances schemes are complicated and its design should be simple and flexible. NGOs play an effective role for the promotion of micro insurance at grass root level.

The highlights of micro insurance regulation 2005 are:

- NGOs and SHGs can act as micro insurance agents and permitted to distribute micro insurance product to people.

- Life insurance products that is available for a maximum period of 15 years.

- The minimum qualification required for appointing micro insurance agent is removed.

- All the micro insurance product should be cleared by IRDA.

- Insurance contracts should be available in local languages of policy holders.

- Micro insurance products should be underwritten by insurance company only.

\section{Types of micro insurance}

- Life insurance: The Life insurance contract provides elements of protection and investment. In Life insurance insurer undertakes to pay a certain sum of money on the expiry of a certain period or on the death of an insured whichever is earlier. There are three types of life insurance coverage term, whole- life, and endowment. Whole life policy provides life time protection.

- Health insurance: It provides coverage against illness and accidents .Disability resulting from illness or accident may be greater peril to family because it cuts off income and creates large medical expenses.

- Property insurance: Property insurance provides coverage against loss or damage of assets. Property insurance consists of agricultural pump set, animal driven cart insurance, hut insurance, gobar gas insurance, and new well insurance. Agricultural pump sets insurance policy indemnifies the insured against unforeseen and sudden physical damage to the pump sets caused by mechanical or electrical breakdown, fire and lightning, theft and burglary. The animal driven cart insurance cover risks against death or permanent total disablement of the animals driving cart. Hut insurance policy indemnifies the insured against all accidental losses or damages due to fire, earthquake and storm. The Gobar gas insurance is applicable to all Khadi and Village industries workers/artisans, IRDP beneficiaries, schedule castes, and schedule tribes.

- Crop Insurance: Crop insurance typically provides policy holders protection in the event their crops are destroyed by natural calamities such as floods or droughts. Crop insurance is mainly to improve the ability of rural farmers to repay the loans. The Government of India introduced National Agricultural Insurance schemes (NAIS) replacing the comprehensive crop insurance schemes with effect from Rabi 1999-2000 season.

- Disaster insurance: Disaster insurance is through a reinsurance arrangement that broadens the risk pool across countries and regions, and protects insurers against catastrophic losses.

- Unemployment insurance: It helps unemployed individuals to find jobs. This insurance provides relief to individuals who become unemployed involuntarily.

Micro insurance schemes in India (updated on $1^{\text {st }} \mathrm{July}$, 2015)
Table 1: (Major Life Insurance companies and their micro insurance schemes)

\begin{tabular}{|c|c|c|}
\hline \begin{tabular}{|l|} 
Year of \\
Launch
\end{tabular} & Name of the scheme & Name of insurer \\
\hline 2001-02 & BSLI Bima Kavach Yojana & \begin{tabular}{|l|} 
Birla Sun Life \\
insurance Co.Ltd
\end{tabular} \\
\hline $2006-07$ & Shri Sahay & $\begin{array}{l}\text { Shriram Life insurance } \\
\text { Co.Ltd }\end{array}$ \\
\hline 2007-08 & BSLI Bima Suraksha Super & \begin{tabular}{|l|} 
Birla Sun Life \\
insurance Co.Ltd
\end{tabular} \\
\hline 2007-08 & BSLI Bima Dhan Sanchay & \begin{tabular}{|l|} 
Birla Sun Life \\
insurance Co.Ltd
\end{tabular} \\
\hline $2012-13$ & SBI Life Grameen Bima & $\begin{array}{l}\text { SBI Life Insurance Co. } \\
\text { Ltd }\end{array}$ \\
\hline 2013-14 & \begin{tabular}{|l|} 
BSLI Grameena Jeevan \\
Raksha plan
\end{tabular} & \begin{tabular}{|l} 
Birla Sun Life \\
insurance Co.Ltd
\end{tabular} \\
\hline 2013-14 & $\begin{array}{l}\text { Canara HSBC-Sampooma } \\
\text { Kavach Plan }\end{array}$ & $\begin{array}{l}\text { Canara HSBC Oriental } \\
\text { bank of Commerce } \\
\text { Life insurance Co. Ltd } \\
\end{array}$ \\
\hline 2013-14 & $\begin{array}{l}\text { DHFL Pramerica Sarv } \\
\text { Suraksha }\end{array}$ & $\begin{array}{l}\text { DHFL Pramerica Life } \\
\text { insurance Co.Ltd }\end{array}$ \\
\hline 2013-14 & $\begin{array}{l}\text { Edelweiss Tokio Life- } \\
\text { Raksha Kavach }\end{array}$ & $\begin{array}{l}\text { Edelweiss Tokio Life } \\
\text { insurance Co.Ltd }\end{array}$ \\
\hline 2013-14 & $\begin{array}{l}\text { Edelweiss Tokio Life-Dhan } \\
\text { Nivesh Bima Yojana }\end{array}$ & $\begin{array}{l}\text { Edelweiss Tokio Life } \\
\text { insurance Co.Ltd }\end{array}$ \\
\hline 2013-14 & $\begin{array}{l}\text { HDFC SL Sarvgrameen } \\
\text { Bachat Yojana }\end{array}$ & $\begin{array}{l}\text { HDFC Standard Life } \\
\text { Insurance Co. Ltd }\end{array}$ \\
\hline 2013-14 & $\begin{array}{l}\text { ICICI Pru Sarv Jana } \\
\text { Suraksha }\end{array}$ & $\begin{array}{l}\text { ICICI Prudential Life } \\
\text { Insurance Co. Ltd }\end{array}$ \\
\hline $2013-14$ & ICICI Pru Anmol Bac & $\begin{array}{l}\text { ICICI Prudential Life } \\
\text { Insurance Co. Ltd }\end{array}$ \\
\hline 2013-14 & $\begin{array}{l}\text { IDBI Fec } \\
\text { insuran }\end{array}$ & $\begin{array}{l}\text { IDBI Federal Life } \\
\text { Insurance Co. Ltd }\end{array}$ \\
\hline 2013-14 & Met Grameen Ashray & $\begin{array}{l}\text { PNB MetLife India } \\
\text { Insurance Co. Ltd }\end{array}$ \\
\hline 2013-14 & $\begin{array}{l}\text { Sahara } \\
\text { Jeevan }\end{array}$ & $\begin{array}{l}\text { Sahara India Life } \\
\text { Insurance Co. Ltd }\end{array}$ \\
\hline 2013-14 & SBI Life Grameen Shakti & $\begin{array}{l}\text { SBI Life Insurance Co. } \\
\text { Ltd }\end{array}$ \\
\hline 2013-14 & \begin{tabular}{|l} 
SBI Life Grar \\
Suraksha
\end{tabular} & $\begin{array}{l}\text { SBI Life Insurance Co. } \\
\text { Ltd }\end{array}$ \\
\hline 2013-14 & LIC's New Jeevan Mangal & \begin{tabular}{|l|} 
Life insurance \\
Corporation of India
\end{tabular} \\
\hline 2013-14 & LIC's Bhagya Lakshmi & \begin{tabular}{|l|} 
Life insurance \\
Corporation of India
\end{tabular} \\
\hline 2013-14 & $\begin{array}{l}\text { Bharti AXA Lif } \\
\text { Suraksha }\end{array}$ & \begin{tabular}{|l|} 
Bharti AXA Life \\
Insurance Co. Ltd
\end{tabular} \\
\hline 2013-14 & Credit Plus & $\begin{array}{l}\text { AVIVA Life Ins.Co. } \\
\text { India Pvt. Ltd } \\
\end{array}$ \\
\hline $2014-15$ & \begin{tabular}{|l|} 
IDBI Federal \\
Termnsurance Sampoom \\
Suraksha Micro insurance \\
plan
\end{tabular} & $\begin{array}{l}\text { IDBI Federal Life } \\
\text { Insurance Co. Ltd }\end{array}$ \\
\hline $2014-15$ & $\begin{array}{l}\text { Kotak Sampoom Bima } \\
\text { Micro insurance plan }\end{array}$ & \begin{tabular}{|l} 
Kotak Mahindra OM \\
Life Insurance Ltd \\
\end{tabular} \\
\hline $2014-15$ & $\begin{array}{l}\text { Tata AJA Life Insurance } \\
\text { Navkalyan Yojana- Micro } \\
\text { insurance product }\end{array}$ & $\begin{array}{l}\text { Tata AJA Life } \\
\text { Insurance Co. Ltd }\end{array}$ \\
\hline $2014-15$ & \begin{tabular}{|l|} 
AAviva Nayi Grameen \\
Suraksha- Mocro \\
Insurance Product
\end{tabular} & $\begin{array}{l}\text { AAVIVA Life Ins.Co. } \\
\text { India Pvt. Ltd }\end{array}$ \\
\hline
\end{tabular}

Source:IRDA website

\section{Growth of Micro Insurance in Rural Areas of India}

Insurance regulatory authority has permitted more institutions to deal in micro insurance. District cooperative banks, RRBs and business correspondents of various scheduled commercial banks can be act as micro insurance agents. It is to achieve better penetration of micro insurance 
business in rural area. As on $31^{\text {st }}$ March 2020 there is thirty two micro insurance products were available in the market for sale. It includes 11 individual products and 21 group products. The protection of low income people is the main aim of micro insurance regulations and it is through the introduction of affordable insurance products to people. As per new insurance regulation Non-Government Organizations and self-help groups can act as an agent of insurance companies in marketing the micro insurance products. The performance of micro insurance business during the year 2019-20 in life insurance sector (Table:2) shows that 10.28 lakh new policies with premium amount Rs.226.66 crore. Under group business, the lives covered were 14.07 crore by charging premium Rs.4426.45 crore. LIC's contribution in individual new business is 8.59 lakh policies with premium of Rs. 222.09. At the same time the contribution of private sector is 1.69 lakh policies in individual new business while in group micro insurance 13.49 crore lives with premium of Rs. 4,391.90.

\begin{tabular}{|c|c|c|c|c|c|}
\hline & & $\mathbf{T a}$ & ble 2 & & \\
\hline & W BUSIN & $\begin{array}{r}\text { JESS UNDE } \\
\text { PORT }\end{array}$ & $\begin{array}{l}\text { R IMICRO } \\
\text { FOLIO }\end{array}$ & INSURAN & \\
\hline & FOR & 2019-20 (F & Premium i & n crore) & \\
\hline Insurer & Indiv & jidual & & Group & \\
\hline & $\begin{array}{l}\text { Policies } \\
\text { (Lakh) }\end{array}$ & Premium & Schemes & Premium & $\begin{array}{c}\text { Lives } \\
\text { covered } \\
\text { (lakh) }\end{array}$ \\
\hline Private & 1.69 & 4.57 & 1 & 4391.90 & 1349.33 \\
\hline LIC & 8.59 & 222.09 & 762 & 34.55 & 57.96 \\
\hline Total & 10.28 & 226.66 & 763 & 4426.45 & 1407.29 \\
\hline
\end{tabular}

\section{Source: IRDA Annual Report}

Micro insurance agents at the end of March 2020 stood at 90,574 (Table 3) of which 20,907 agents of LIC and the remaining 69,667 represented the private sector companies. Out of total 90,574 micro insurance agents of life insurers, 7 per cent constitute NGO's, Self-help group form 0.4 per cent and Micro finance institutions also only 0.4 per cent. Majority, 92 per cent constitute other micro insurance agents.

Table 3. Micro Insurance Agents Of Life Insurers (201920)

\begin{tabular}{|l|c|c|c|}
\hline Agents & LIC & Private Sector & Total \\
\hline NGO's & 6504 & 111 & 6,615 \\
\hline MFI's & 295 & 27 & 322 \\
\hline SHG's & 336 & 17 & 353 \\
\hline Business correspondents & 101 & 32 & 133 \\
\hline Other Micro insurance Agents & 13671 & 69480 & 83151 \\
\hline Total & 20907 & 69667 & 90,574 \\
\hline
\end{tabular}

\section{Source:IRDA Annual Report}

Challenges for the development of micro insurance in rural areas

- Providing micro insurance coverage in rural areas is very difficult task than in urban settings.

- Low educational level, low income and financial capacity of people in rural area makes the sales and pricing of micro insurance product more difficult.

- Lack of adequate channels like banking to make the distribution successfully. It can be noticed that the risk assessment is difficult due to the absence of mortality data.

- Service providers in micro insurances are not active in rural areas. They are not well equipped to transfer their know-how to their client. Clients face lot of difficulties in understanding technology introduced by the service providers.

- Lack of unfamiliarity and trust on the service provides is an important issue related to micro insurance in rural area.

- Irregular cash flows of households affect their capacity of paying the premium regularly.

- Challenges such as affordability, insurance literacy and consumer protection, need a special look

\section{CONCLUSION}

The protection of low income people is the main aim of micro insurance regulations and it is through the introduction of affordable insurance products to people. These insurance products will help the people to recover from common risks. As per new insurance regulation Non-Government Organizations and self-help groups can act as an agent of insurance companies in marketing the micro insurance product. The objective of micro insurance is providing economic security to low income people.Both private and public insurance companies take initiatives in the growth of rural India. Service providers in micro insurances are not active in rural areas. Flexible insurance premium payment should be attached to insurance products. It is better to provide awareness on technology introduced by the service providers. By minimising the documentation and developing efficient, transparent claims processing system we can develop the micro insurance schemes in rural India.

\section{REFERENCES}

1. Mishra, M.N and S.B.Mishra (2010). Insurance principles and practice, $17^{\text {th }}$ Edition.S.Chand \&Company Ltd

2. Ratna Kishor, N(2013). Micro insurance in India-protecting the poor, Blue Ocean Research Journal-Vol.2,No3

3. International Micro insurance Conference 2008, "'Making Insurance work for the poor", November 2008.

4. Sairam, R(2009). LIC targets 40000 micro insurance policies from Southern districts this fiscal,The Hindu Madurai

5. Rajeev Ahuja, Basudeb Guha-Khanobis (2005). Micro insurance in India Trends strategies for further extension, Indian Council for research on international economic relations, New Delhi

6. Microinsurance innovative facility protecting the working poor",Annual Report 201 1-International Labour Office, ISBN 978-92-2-125898-8

7. Annual report 2019-2020, IRDA (Insurance Regulatory and Development Authority of India.

8. Ramalakshmi,C and Dr. L.P Ramalingam(2014). A Study on Awareness about Micro insurance with special reference to LIC of I ndia, International Journal of Advance Research in Computer Science and Management Studies, Volume2,Issue 9

9. Sanjeev Kumar Srivastava(2013) Micro Insurance:a spectacularView on Rural Development in India, Indian journal of applied research,Vol-3,Issue 8

10. Farah Farooque (2013). Role of micro finance institutions in Micro insurance, Global journal of Management and Business studies, Vol-3, No.5, pp.535-540.

11. Bhat Shilpa, R(2012) A study of financial performance appraisal of LIC of India, PhD Thesis, Saurashtra University

12. Basanta. K.Sahu(2010) Microinsurance in India: Outreach\& efficacy, Centre for Microfinance Research(CMR) Report, issue 5 